The

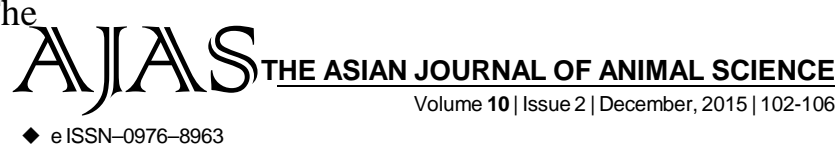

DOI : 10.15740/HAS/TAJAS/10.2/102-10 Visit us | www.researchjournal.co.in $\mathbf{S}$

RESEARCH ARTICLE.

\title{
Effect of non-genetic factors on weaning body weight and measurements in Konkan Kanyal goats
}

D.J. BHAGAT AND R.G. BURTE

.

\begin{abstract}
Data of 876 observations of body weight and measurements at weaning age of Konkan Kanyal goats were collected from records maintained at Livestock Research Station, Nileli. It was revealed that the average body weight and measurements at weaning age as

Author for Corresponding -

\section{D.J. BHAGAT}

Department of Animal Husbandry and Dairy Science,

College of Agriculture, Dr.

$8.67 \pm 0.055 \mathrm{~kg}$ body weight and $49.25 \pm 0.072 \mathrm{~cm}$ height at wither, $47.74 \pm 0.06 \mathrm{~cm}$ body length and $46.53 \pm 0.063 \mathrm{~cm}$ hearth girth, respectively. The effect of year of birth, season of birth, sex and birth weight had significantly affected on body weight and all the body measurements at weaning age (3 months). However, the type of birth had not significantly affected on weaning body weight and all the body measurements in Konkan Kanyal kids.
\end{abstract}

Balasaheb Sawant Konkan Krishi

Vidyapeeth, Dapoli,

RATNAGIRI (M.S.) INDIA

Email: djbhagat2010@gmail.com

See end of the article for

Coopted authors'
KEY WORDS...... Konkan Kanyal goat, Non-genetic factor, Weaning age

HOW TO CITE THIS ARTICLE - Bhagat, D.J. and Burte, R.G. (2015). Effect of non-genetic factors on weaning body weight and measurements in Konkan Kanyal goats. Asian J. Animal Sci., 10(2): 102-106.

ARTICLE CHRONICLE - Received : 29.06.2015; Revised : 07.10.2015; Accepted : 21.10.2015 